\title{
Greenwich Meanings: Clocks and Things in Modernist and Postmodernist Fiction ${ }^{1}$
}

\author{
Randall Stevenson \\ University of Edinburgh
}

\begin{abstract}
The clock inside the Gare du Nord read 11:17: Paris time minus five minutes, Belgian railway time plus four minutes, mid-Europe time minus 56 minutes. To Mélanie, who had forgotten her travelling clock - who had forgotten everything - the hands might have stood anywhere ....

By the cover of Le Soleil, the Orleanist morning paper, it was 24 July 1913. Louis Philippe Robert, duc d'Orleans, was the current Pretender. Certain quarters of Paris raved under the heat of Sirius....

Mélanie l'Heuremaudit was driven away down the rue La Fayette in a noisy auto-taxi . . .
\end{abstract}

Historical stresses underlying much twentieth-century fiction, modernist and postmodernist, are to be found in Chapter 14 of Thomas Pynchon's $V$., not least in the strange chronology described in its opening, quoted above (369), and emphasised by Mélanie's second name, which translates as 'the accursed hour.' Typically of Pynchon's fiction, those clocks seem odd but have a firm historical basis. In A la recherche du temps perdu, Proust also refers to the survival of a separate mid-European time, and of the use of the Eastern calendar, into the early decades of the twentieth century. Within France, to help tardy travellers catch their trains, station clocks in 1913 still kept 'l'heure de la gare,' five minutes slower, as Pynchon suggests, than the 'Paris time' shown on all the capital's other clocks. Belgian trains, on the other hand, still ran exactly on Brussels time, different from that of Paris in the early years of the century. Mélanie's loss of her travelling clock at least saves her the irritation of having to reset it in the course of her journey from Belgium-a task often necessary for railway travellers in the nineteenth century, and as Pynchon shows, into the early part of the twentieth, at least on the Continent.

Travelling clocks of a different sort had already ended this problem within Britain. Railway companies in the mid-nineteenth century sent officials with accurate chronometers up and down the country, resetting station clocks to eliminate local times in favour of a national standard, Railway Time, established more or less throughout the land by 1848 . It was further institutionalised as part of the new global standards set up by the International Meridian Conference of 1884, which answered the needs of travel, shipping, telegraphy and other commercial interests by placing the Prime Meridian at Greenwich Observatory, also established as the centre of a world-wide system of time zones and Mean Time. Contemporary public interest in these new arrangements is evident in Arthur Wing Pinero's The

\footnotetext{
${ }^{1}$ A shorter version of this paper was first published in The Yearbook of English Studies: 2000. This version, delivered in Seville on 21 October 1999, is reproduced here with the generous permission of the Yearbook's editor, Nicola Bradbury.
} 
Magistrate, first performed the year after the Conference: when asked about the time, its hero cheerfully replies "Hurray! Just half-past ten. Greenwich mean, eh Guv?" (21). Ulysses shows Bloom pondering in 1904 the technology through which the new standard time was disseminated throughout the British Isles when he notices a Dublin time-signal "that falls at Greenwich time. It's the clock is worked by an electric wire from Dunsink" (211).

Ireland, however, did not fully accept Greenwich Mean Time until 1916 (it had been officially accepted in Spain by 1901), and other countries were similarly tardy, France particularly. For patriotic reasons, France had always favoured Paris over Greenwich as the location of the Prime Meridian, and was consequently dilatory and eventually devious in implementing the new arrangements. GMT was legally accepted as the time of France in 1896, but it was not until fifteen years later that much was done to implement it, and even then only by referring to it as "Paris time minus nine minutes and twenty-one seconds"hence that 9-minute difference from Brussels, working on GMT since 1892, which Pynchon identifies. ${ }^{2}$ Indeed, France's official time continued to be defined in this way until 1978, and residual resentment of Greenwich, and national pride in the superseded Paris meridian, lasted still longer. It was spectacularly in evidence in the millennial plans, announced in 1999 , for a $14^{\text {th }}$-of-July picnic in the year 2000 , involving as many as 3 million people, to be held exactly along the line of the meridian in Paris, and in 337 other towns and villages, with this line to be further, permanently marked on the physical landscape by the planting of 660 kilometres of olives, oaks and yews. In France at least, the twenty-first century was to begin with a more palpable than ever allegiance to the new measures of time and space defined at the end of the nineteenth.

Even when France did finally cease referring to Paris time in 1978, it was in favour of a measure, Co-Ordinated Universal Time, now generally accepted as the world standard at the end of the twentieth century, which originally owed less to British efforts than to further conferences on time initiated by the French in Paris in 1912 and 1913. These did encourage wider acceptance of GMT, but also set up a Bureau International de l'Heure to establish with scientific precision 'l'heure définitive,' to be disseminated throughout the whole world by means of radio time signals: the first of these was broadcast from the Eiffel Tower on 1 July 1913. Some of the Bureau's other work was interrupted by the First World War'l'heure définitive' was not finally established until 1 January 1920_but it was ultimately made still more necessary by demands war made for exactly-timed co-ordination of troop movements and telegraphy. As Stephen Kern shows in The Culture of Time and Space 1880-1918, the war was in one way almost the result of new technologies and timetables ruling life-general mobilisations creating a momentum of co-ordinated movements and timings, especially of railway transport, too complex and powerful for any individual diplomat to stop once they had been initiated at the end of July 1914.

\footnotetext{
${ }^{2}$ For this and other details of time-measurement early in the twentieth century, see Derek Howse, Greenwich Time and the Discovery of the Longitude (Oxford: Oxford University Press, 1980). As France did finally readjust its clocks in March 1911, two years before the date of Mélanie's arrival, it seems Pynchon's description of Paris time may itself be slightly anachronistic.
} 
Pynchon's description of Paris life a year earlier therefore identifies a highly specific historic moment. While the very air around the Gare du Nord in July 1913 pulsed with the new, universal exactitude of time-signals first beamed from the Eiffel Tower only a few weeks previously, contradictory clocks in the station and the streets around sustained vestiges of the kind of diversity and local idiosyncrasy characteristic of European experience of time in earlier ages. Mélanie's readiness to forget the clock altogether is in another way equally characteristic - of earlier ages, certainly, but also in many ways of a contemporary one sometimes as ready to react against new exactitudes imposed by the clock, even to let its hands stand anywhere, as to be ruled by any 'heure définitive.' Science and business interests worked steadily, in the period from 1884 to 1920, towards the establishment of an exact, global, public time, ${ }^{3}$ but a number of other areas-philosophical, literary, sometimes political—exhibited reciprocal and sometimes almost simultaneous movements in contrary directions. Even within science itself, denials of any absolute, Newtonian concept of space and time began to appear in Ernst Mach's work in 1883, just before the International Meridian Conference. Mach's kind of thinking was greatly advanced in Einstein's ideas of Relativity, his General Theory apparently confirmed, following observations of the solar eclipse of 1919, at a sensational meeting of the Royal Society in November of that year. Just a few weeks, in other words, before the establishment of 'l'heure définitive' on 1 January 1920, Einstein proposed with what seemed scientific certitude that no definitive or universally valid scale of time could be assumed to exist at all.

Such thinking created immediate and enormous public interest, summed up in 1923 in D.H. Lawrence view that "everyone catches fire at the word Relativity. There must be something in the mere suggestion which we have been waiting for" (177). Contemporary fiction, Lawrence's included, reflects late-nineteenth and early twentieth-century developments which naturally made appealing any suggestion that the clock could be forgotten or ignored, at least in the new, rigorous role Greenwich had created for it. A definitive, universal temporality had quickly enabled much more precise controls of time in the workplace, and firmer measures for its conversion into wages: increasingly, time could be exactly commodified, and so simply equated with money. The use of clocking-in machines had become widespread even by the 1890s: time-and-motion measurements of labour contributed to the Principles of Scientific Management Frederick Winslow Taylor completed in 1911 , concluding that "in the past the man has been first; in the future, the system must be first." Based on "rules, laws and formulae" $(22,8)$, Taylor's kind of system was enthusiastically implemented in Henry Ford's production-line methods, largely in place by 1913. Full literary reflection of these developments had to wait for Aldous Huxley's portrayal in Brave New World of a society in which Ford has become the deity, 'Big Henry' has re-

\footnotetext{
${ }^{3}$ Similar interests agitated at the time, though eventually unsuccessfully, for reform of the calendar. See for example Armand Barr, La Réforme du Calendrier (Liège: Charles Desoer, 1912) which sums up resolutions taken at the Congrès International des Chambres de Commerce et des Associations Commerciales et Industrielles of 1910 and explains in its Préface 'il s'agit de gagner de temps, et donc de l'argent'. It may be worth noticing that Mélanie's arrival in Paris is as confused calendrically as it is horologically: though Le Soleil suggests that she arrives on 24 July, by the end of her short taxi ride to rue Germaine Pilon, she emerges into 'uncertain August daylight' (p.371). Perhaps Pynchon-interested in Mason \& Dixon (1997) in the eleven days once removed from the calendar-is practising here some calendrical experiment of his own
} 
placed Big Ben, "four thousand electric clocks" (29) control the place of work, and "the principle of mass production [is] at last applied to biology" (5)—creating workers no longer reduced only metaphorically to cogs in an assembly-line machine, but quite literally produced by one. Ten years earlier, however, Lawrence had shown in Women in Love the principles if not of Fordism at least of Taylorism at work in Gerald Crich's modernisation and rationalisation of his mine. This employs "the most accurate and delicate scientific method" to create "a new order, strict, terrible, inhuman . . . a great and perfect system that subjected life to pure mathematical principles" (259-60), threatening to make all those involved into "mechanisms . . . perfect parts of a great machine" (524). Ironically, one of the lives so subjected is Gerald's own; obsession with profit, system and mechanisation leaving him, in Gudrun's judgement, with only "a lot of little wheels to his make up ... more intricate than a chronometer-watch" (525).

The extent to which the clock functioned as a prime agent in this kind of rationalisation and mechanisation in an industrial age receives a fuller, non-fictional treatment in the 1920 s - part of an analysis of the general historical and economic conditions of the timein Georg Lukács's History and Class Consciousness. In his essay "Reification and the Consciousness of the Proletariat," Lukács concludes that "with the modern . . . analysis of the work-process (in Taylorism),"

rational mechanisation extends right into the worker's 'soul' . . . He is a mechanical part incorporated into a mechanical system. . . Marx puts it thus 'Through the subordination of man to the machine the situation arises in which ... time is everything, man is nothing, he is at the most the incarnation of time. ... Time sheds its qualitative, variable, flowing nature; it freezes into an exactly delimited, quantifiable continuum filled with quantifiable 'things' (the reified, mechanically objectified 'performance' of the worker, wholly separated from his total human personality). (88-90)

Lukács's lexis - of mechanical parts and systems-is at times close to Lawrence's. His idea of time 'freezing' into quantifiable units is likewise comparable to some of the philosophy of Henri Bergson, who had begun within a few years of the International Meridian Conference-with his Essai sur les données immédiates de la conscience in 1889-to propound the idea that clockwork division of the flowing continuity of life into quantifiable temporal units was a fundamental conceptual error. For all these writers, the clock and its precise hours had indeed become a kind of curse. However convenient for scientists, businessmen or railway travellers, new systematisation of time had become a key component in latenineteenth and early twentieth-century industrial and economic developments which had left the "total human personality" reduced, reified and subordinated within processes of increasingly soulless automation and mechanisation.

Reification is also a central concern of $V$, and various confusions-or interfusions-of human and inanimate, person and machine, reach an almost literal climax in Chapter 14. Brought to Paris to perform in a ballet featuring "the use of automata," Mélanie is soon experiencing sexy dreams about a faceless creature who winds her up like some strange a clockwork artefact (372). In reality, she becomes the fetish-"not real but an object of pleasure" (379)—for the lady V., whose awareness of "her own progression toward inanimateness" (385) makes it difficult for her to sustain sexual relations in any other way. 
Chapter 14 also proposes a kind of theory for these and other processes of reification $V$. depicts when a character suggests that

a decadence ... is a falling-away from what is human . . because we are less human, we foist off the humanity we have lost on inanimate objects and abstract theories. (380)

Followed in $V$. from the later nineteenth century until 1956, this kind of 'decadence' comes to seem a fundamental determinant of all politics and history. This role is hinted at in Profane's disturbing 'conversation' with the robot SHROUD, and developed in Stencil's conclusion that

sometime between 1859 and 1919, the world contracted a disease which no one ever took the trouble to diagnose because the symptoms were too subtle-blending in with the events of history, no different one by one but altogether-fatal. (433)

$\mathrm{V}$. herself is the prime agent and exemplar of this 'disease,' and her progressive reification-eventually literal and prosthetic-includes a bizarrely horological aspect. In putative incarnations as Vera Merroving in 1922, and later as the bad priest in Valetta in the Second World War, V. wears a "glass eye with the iris in the shape of a clock" (322). With "the delicately-wrought wheels, springs, ratchets of a watch" clearly visible inside it, it looks "like the evil eye of time itself" $(219,363)$. V.'s 'evil eye' once again suggests 'l'heure maudite,' time as a curse, confirming that if reification is a principal disease or blight of the late nineteenth and twentieth centuries, the clock is its perennial accompaniment, whether as cause or symptom.

$V$. also identifies, though sometimes more obliquely, forces which have resisted this historical disease, not just philosophically or conceptually but actively and politically. Some of these also figure in Chapter 14, which shows the composer of Mélanie's ballet fraternising with "a strange collection of Russian expatriates ... engaged in clandestine political activity, they spoke volubly and at length of Bakunin, Marx, Ulyanov" (380). References to anarchism, often of Bakunin's variety - to the kind of 'anarchist miracle' discussed in The Crying of Lot 49, for example-thread their way through a good deal of Pynchon's writing, and have in V., as usual, an authentic historical background. ${ }^{4}$ As well as witnessing vestiges of royalist support for the duc d'Orleans-sometimes in the form of the violent 'camelots du roi' affiliated to the nascent Action Française-Paris in the summer of 1913 was also the scene of a number of anarchist riots, including one a month after Mélanie's stated date of arrival in Belleville, presumably one of the quarters which 'raved under the heat of Sirius.' On 24 August, a mile or so from the Gare du Nord, anarchist supporters singing the 'Internationale' and yelling 'l'Anarchie!' marched along the rue de Belleville, shot out its streetlights and then exchanged fire with the police in the gendarmerie in the appropriately-named rue du Combat. Their agitation paralleled struggles by the Confédération Génerale du Travail, throughout the summer of 1913, to reduce the hours of the working day and the number of working hours in the week.

\footnotetext{
${ }^{4}$ On Pynchon's tendency to hint at historical occurrences-sometimes specifically connected with anarchy and anarchists-whose significance is not made fully available to readers by his text, see Colin Nicholson and Randall Stevenson, "Words you Never Wanted to Hear': Fiction, History and Narratology in The Crying of Lot 49" in Pynchon Notes, 16, Spring 1985, 89-109.
} 
There are other instances throughout the industrial age of socialist, anarchist, or related political movements recognising the importance of the 'accursed hour' for systems of power they sought to resist, and sometimes creating an almost symbolic role for the clock as a result. Outbreaks of a kind of horological Luddism long predate the establishment of Greenwich Mean. Walter Benjamin records of the July Revolution of 1830-which installed Louis Philippe Robert's great-grandfather as King of France-that "on the first evening of fighting it turned out that the clocks in towers were being fired on simultaneously and independently from several places in Paris," as though the revolutionaries were "irrités contre l'heure" (262). Perhaps the anarchist resistance to factory-based labour among the watchmakers of the Jura whom Bakunin visited in 1867-as Pynchon mentions in The Crying of Lot 49-and which later so impressed another anarchist, Prince Kropotkin, owed its inspiration to work in clock-making which allowed the workers an early realisation of what clocks themselves were making of the modern world. Much the most significant nineteenth-century anarchist act, however-at least for students of literature-is the episode Joseph Conrad develops in The Secret Agent and describes in his "Author's Note" to the novel as "the old story of the attempt to blow up the Greenwich Observatory . . . impossible to fathom . . . by any reasonable or even unreasonable process of thought" (5). Newspaper accounts Conrad may have read of the original outrage in 1894 certainly do little to establish reasonable motives for it, uniformly failing to notice that year as the tenth anniversary of Greenwich's systematisation of world space and time-or that this function had made the Observatory, as Stephen Kern reflects, such a "graphic symbol of centralized political authority" that "a more appropriate anarchist objective" could not have been found (16). ${ }^{5}$ Conrad ensures this role is emphasised in The Secret Agent by setting the novel in 1886, just two years after the International Meridian Conference, at a time when the novelty of the new arrangements would still ensure that, as Vladimr suggests to Verloc (and as Pinero's play of the previous year confirms), "the whole world has heard of Greenwich" and so "the blowing up of the first meridian is bound to raise a howl of execration" (37).

Conrad's work in the merchant navy-he passed mariners' examinations as first mate in 1884 , and as master in 1886 - made him much more than usually reliant on Means and Meridians, and might naturally have disposed him to share in 'execration' at anarchist attempts to destroy them. And anarchism in The Secret Agent-at least as personified by Verloc, Ossipon, and their cohorts-receives little apparent sympathy. Yet there is evidence in Conrad's fiction, The Secret Agent included, to suggest its author at least recognisedperhaps prepared after all by that early career at sea, and at any rate well in advance of other modernist writers - the kind of stresses imposed on the 'total human personality' by great and perfect new systems Greenwich had helped impose on modern life. Something of this is suggested in Lord Jim when Captain Brierly neatly charts his ship's position "with a tiny cross and ... the date and time" (50) then carefully ties his "gold chronometer watch" (52), a reward for outstanding service, to the rail of his ship and jumps overboard to lose himself forever in the vastness of the sea-a gesture of rejection of rigorous systematisation

\footnotetext{
${ }^{5}$ On the oddity of contemporary newspaper reactions to the Greenwich bombing, see Randall Stevenson, "A Narrow, Zigzag, and Secluded Path: Conrad, Clockwork, and the Politics of Modernism" in Andreas Fischer, Martin Heusser and Thomas Hermann, eds. Aspects of Modernism (Tübingen: Gunter Narr Verlag, 1997), 33-52.
} 
of space and time, in the work of an early modernist writer, reduplicated with intriguing exactness toward the end of the modernist period by the actions of William Faulkner's protagonist in "The Bear." Elsewhere in Lord Jim, too, and in later Conrad novels, moments of tension or crisis are often comparably connected with the insistent activity of watches or clocks. In Verloc's house in The Secret Agent, "the lonely ticking of the clock on the landing stole into the room as if for the sake of company" (149) and clocks are likewise portrayed throughout as sinisterly animate, or even hostile. Such descriptions share in a wider pattern of personification and reification in the novel which ascribes, for example, a mind and will to the 'lonely' bar-room piano accompanying Ossipon's colloquies with the Professor, while describing Verloc as "like an automaton" and Stevie as eventually no more than "an accumulation of raw material" $(162,77)$.

The Secret Agent thus highlights symptoms of the same disease or decadence which Stencil diagnoses running throughout modern history in $V$., and which can be found regularly reflected in twentieth-century fiction by the time of Lawrence and Huxley. Conrad's most significant anticipation of later writing, however, is in suggesting antidotes which are not directly political-certainly not in terms of approving anarchist action against Greenwich-but imaginative and aesthetic. The Secret Agent comprehensively resists strict chronology at the level of form-through the extensive anachronies and zigzag assemblage of its own narrative, constructed as if to exemplify Chief Inspector Heat's conclusion that there can be "unexpected solutions of continuity, sudden holes in space and time" (76). Comparable conclusions, and comparable tactics, inform many modernist narratives. The kind of "shredding and slicing, dividing and subdividing" (113) clocks which figure in Virginia Woolf's Mrs Dalloway, for example, are escaped through narratives which turn away from the reifying pressures of modern life towards more inviolate inner states of consciousness-ones which allow what Woolf calls "time in the mind" to replace the rigours of public time, its divisions and subdivisions dissolved in a seamless, anachronous stream of mingling memories and impressions. ${ }^{7}$

Such tactics, of course, have been widely recognised and discussed as one of the distinctive, defining characteristics of modernist narrative in the first decades of the twentieth century. Fredric Jameson concludes that it "has become a commonplace of modernist criticism" to find "an original and historically new sense of temporality . . . the constitutive feature of a now classical modernism, rather than of a language-centred postmodernism" (1979 123). ${ }^{8}$ Though Jameson is right to see postmodernist writing dominated by selfreflexive concerns with its own medium, and therefore primarily 'language-centred,' con-

\footnotetext{
${ }^{6}$ Clocks and watches, of course, regularly occupy a peculiar place in modernist fiction - think also of Quentin Compson's watch in Faulkner's The Sound and the Fury, as well as the instances in Mrs Dalloway mentioned above. The specific symmetry of Brierly with Faulkner's hero, however, emerged for me during the Seville conference in discussion with Paul Witkowsky and Francisco Collado.

${ }^{7}$ Woolf discusses the "extraordinary discrepancy between time on the clock and time in the mind" in Orlando (1928; rpt. Harmondsworth: Penguin, 1975), 69.

${ }^{8}$ Georg Lukács also points in "The Ideology of Modernism" (1957) to an altered temporality as a "constitutive feature' of modernism, but makes no real connection with the kind of conclusions he reached in "Reification and the Consciousness of the Proletariat," suggesting only that it is one further example of modernism's 'denial of history.'
} 
cern about new temporalities and rationalisations dependent upon them does continue at least as a significant subsidiary concern of a postmodern age later in the century, as the example of $V$., published in 1963, helps to show. Though much of the novel is set in the modernist years early in the century, the anxieties it identifies in that period are also shown strongly extending towards the present day, or at any rate as far as the novel's 'present' of 1956. To return again to Chapter 14, the lady V.'s reification-advanced enough in Paris by 1913 - grows still more alarming in Stencil's daydreams of how it might be extended by adjuncts of advanced technology available in the latter half of the twentieth century. For Brian McHale, however, discussing the novel in his study Postmodernist Fiction, V. remains so bound up in interests and strategies typical of the modernist period as to be more of a "stylisation ... of modernist fiction" than a postmodernist text in its own right (21). Perhaps more postmodernist characteristics might be found for $V$. than the fantasy McHale is ready to acknowledge: Stencil's insistent diagnoses of disease in history accumulate into a kind of grand narrative as rigid and constraining, in its own way, as the reification that preys upon the lady V., leaving the novel itself, in rather a postmodernist manner, selfconsciously interrogative of some of the textual or interpretative strategies practised within it. But there are in any case novels of more impeccably postmodernist pedigree than $V$., and published more centrally within the postmodernist period, which clearly continue to demonstrate the concerns with chronology and reification outlined above.

One of these is Alasdair Gray's Lanark, which flaunts its postmodernist credentialsparody, fantasy, ludic self-reflexiveness, even acknowledged plagiarism-flagrantly enough to suggest its author might be half-afraid readers might not recognise them. Lanark is equally full of multilayered anxieties about clocks, time, and their rigorous shaping of life. Even in one of its naturalistic sections, in Book 1 (though nowhere near the start of the novel: its Books appear in the order 3, 1,2,4), a character describes his working life as one in which "You get up, dress, eat, go tae work, clock in etcetera etcetera automatically, and think about nothing but the pay packet .. . Life's easy when you're a robot" (216). Life is still more automated and reified in the futuristic, fantasy domains of the Institute and of Unthank, described in Books 3 and 4. These are controlled by a global, technologised capitalist industry- "a conspiracy which owns and manipulates everything for profit" (410)which has powerfully reinforced the old Taylorist equation of money and time: its advertising exhorts "MONEY IS TIME. TIME IS LIFE. BUY MORE LIFE FOR YOUR FAMILY . . . THEY'LL LOVE YOU FOR IT"' (454). Strategies of this profitconspiracy extend to the imposition of a 'decimal hour' and a "decimal calendar based on the twenty-five-hour day": attempts to resist it include a "department of chronometry" which seeks to restore the old divisions of time by rescuing antique clocks from museums, setting them going again and ensuring that "church towers with bells" will be synchronised with their chimes $(416,452)$.

Gray's fantasy, in other words, projects a future world in which capitalist control of the dimension of time has become extreme enough actually to encourage a kind of nostalgia for "the old timekeeping" (408) in the form of the Mean old system of Greenwich. Naturally enough, however, the novel also shows a longing to escape absolutely and entirely from temporal and other systems and conspiracies. When Lanark and his lover Rima flee the 
Institute, and before they are once again absorbed in Unthank, they find themselves in an 'Intercalendrical Zone' whose zany indeterminacies of space and time-much resembling the landscape of Wyndham Lewis's The Childermass - offer some relief from the urbanised, technologised domains they otherwise inhabit. Full of sand, wrecks and toadstools, it is hardly a pastoral idyll - though maybe as close to one as a future hyper-industrial world can expect-but is nevertheless the place where Rima finds herself reabsorbed into one natural cycle of time, pregnancy. Though the child who results can do little to redeem the hellish world Lanark depicts, he does at least offer its hero a limited sense of hope and freedom-even, paradoxically, from the determining constraints of the text in which he appears, since the god-like author-figure encountered in the Epilogue, placed in the middle of Book 4, claims that no child ever figured in his knowledge or plans for the book.

Significantly, too, Lanark and Rima make their escape into the Intercalendrical Zone through a door marked "Exit 3124"- -just the order, of course, of the Books which make up the novel; that author-figure explaining "I want Lanark to be read in one order but eventually thought of in another" (483). Like so much modernist fiction, Lanark in this way continues to demonstrate that the temporal systems which constrain and commodify twentiethcentury experience can still be escaped or reordered in art, imagination and narrative, if hardly any longer in fact. Lanark is by no means alone among postmodernist novels in following on from modernism in this way. One of rather few commentators to concern themselves usefully with the temporality of postmodernist fiction, Ursula K. Heise, reaches in Chronoschisms the intriguing conclusion that B.S. Johnson's aims in his celebrated loose-leaf novel-in-a-box The Unfortunates are "not in principle unlike Proust's"-its unbound, physical disjuncture merely mimetic in more radical ways of essentially the same fragmentary, random operations of memory which occupy Marcel's narrative in A la recherche du temps perdu (53). As Heise acknowledges, other postmodernist texts might likewise be considered to reprise, though often to extend through still more radical strategies and structures, departures from chronological order which remain comparable to those initiated by modernism. Out of a wide range that might be mentioned, other examples could include Lawrence Durrell's The Alexandria Quartet- "not travelling from a to b but standing above time" (198)—or Rayner Heppenstall's Two Moons (1977), its twin narratives reproduced alternately down left- and right-hand pages of the text; or the fragmentary construction sustained by John Berger in G. (1972).

Heise's argument, however, is concerned not only to show postmodernist writing extending or radicalising modernist tropes, but also to outline ways such writing supposedly responds to an "altered culture of time" (67)—one in which media and information technologies and other factors in the globalisation and technologisation of contemporary life have foreshortened any sense of the present; heightened awareness of simultaneity; and made several other alterations to the temporality familiar to modernism. Heise's work is obviously useful in emphasising altered conditions and pressures within postmodern temporality, though as the example of Lanark and $V$. help suggest, she might recognise further than she does how often these are simply intensifications of the old; how far postmodernist texts reflect what are only more complex, threatening versions of stresses already well established by the opening of the twentieth century. As she suggests, however, even when 
postmodernist writing does examine comparable problems, it does not-and indeed cannot-always seek the sorts of solutions the modernists did. Fredric Jameson's conclusion in Postmodernism, or, The Cultural Logic of Late Capitalism that William Gibson and cyberpunk are "the supreme literary expression if not of postmodernism, then of late capitalism itself" (419) indicates a useful context for examining the advanced, intensifying stresses of a 'late' capitalism within postmodern imagination. Gibson's futuristic, cyberpunk novel Neuromancer is almost a sufficient example on its own to make clear why modernist aesthetics may no longer be wholly viable in dealing with these expanding stresses, or at any rate why postmodernist writers fear they may soon not be. Readers of Gray or Pynchon might nevertheless find much that is familiar in Neuromancer-such as Gibson's accounts of "corporate power . . the multinationals that shaped the course of human history" (242), or of the ways these agencies help enforce "gradual and willing accommodation of the machine, the system" (243). Machines, indeed, look like the ultimate inheritors of the earth in Neuromancer, with the AIs, the Artificial Intelligences, achieving more or less complete mastery over human ones by the end of the novel. Mechanism and the inanimate also grow increasingly interchangeable with a reified humanity; with the human body itself apparently engaged in a 'gradual accommodation of the machine.' A kind of late extension of the lady V., Gibson's razorgirl heroine Molly is only one of many characters who engage in supposed prosthetic self-improvement, with retractable scalpel-blades secreted beneath her fingernails and mirror glasses surgically inset into her eye sockets.

In other ways, however, the vision of Neuromancer is more sinister even than Lanark or $V$., and much more so than the modernists.' Mechanical modification of the body in Gibson's novel is matched by various forms, neural and other, of reshaping the mind. Case's entry into cyberspace installs "in the bloodlit dark behind his eyes . . . symbols, figures, faces, a blurred, fragmented mandala of visual information," while other forms of technology allow him a similarly virtual-reality entry into Molly's sensorium, which becomes effectively a "mind he shared . . . sensations with" $(68,72)$. The private, inner consciousness favoured by modernist writers, in other words-that last room of one's own in which interior monologues or streams of consciousness could escape or restructure some of the stresses of modernity-virtually ceases in cyberpunk to offer privacy or autonomy to the individual at all. Instead, it becomes merely co-extensive with huge fields of information deployed by computers in the service of multinational corporate power. Though there are ways in which Neuromancer suggests such developments may be less a breach than an expansion of individual consciousness, they leave less freedom than ever from the constraints of regulated time. Part of Molly's prosthetic apparatus is a "readout chipped into [her] optic nerve" (44) which allows her, for example, to tell Case that their first sexual encounter begins at exactly 2:43:12 AM. Hardly what Virginia Woolf meant by 'time in the mind': indeed, just the opposite, inner consciousness no longer offering any escape from chronology, but merely a still more intimate encounter with a clock which has now installed itself even in the 'bloodlit dark' behind the eyes. The kind of clock-based 'rational mechanisation' which Lukács feared as a legacy of nineteenth-century industrialisation thus threatens to extend, by the end of the twentieth, not only into the 'soul' but throughout mind and vision as well, in ways which aesthetic reconfiguration of the imagination may be 
less and less able to resist. Neuromancer provides a kind of hundredth-anniversary commentary on some of the processes that International Meridian Conference initiated-and a sort of grim sequel to Pinero's cheery "Greenwich mean, eh guv?"--when Molly replies to Case's question about her microchip by telling him "it's eight twenty-five, PM, Greenwich fucking Mean" (300).

As her comment emphasises, 'l'heure définitive,' during the twentieth century, has become more and more synonymous with 'l'heure maudite,' the hour as curse. Yet the clock's constraint on twentieth-century life and consciousness has on the whole become less and less recognisable: any sense of its arbitrariness and artificiality has diminished almost in proportion to the growing extent of its influence. Guy Debord complains in Society of the Spectacle that

the irreversible time of production is first of all the measure of commodities. Therefore the time officially affirmed over the entire expanse of the globe as the general time of society refers only to the specialized interests which constitute it and is no more than a particular time ... a time transformed by industry. (Sections 146, 151)

Yet this highly particular temporality has been universalised and made to seem inevitable to the point where it has become almost invisible, as though the clock had installed itself not only within the eyes of Molly and the lady V., but within the perceptual habits of the population as a whole, so that clock-time simply appears an ingrained part of the late twentiethcentury landscape; a 'natural' aspect of the way everything is seen. Just as Yossarian tauntingly suggests of Appleby in Joseph Heller's Catch-22 that he has "flies in [his] eyes ... that's probably why [he] can't see them" (61) it is the constituents of perceptual and conceptual apparatus themselves - in this case, the effects of a constructed temporalitywhich remain most 'invisible' and difficult to return to the field of vision and analysis. Even in a postmodern age which is in other ways so consistently sceptical of all faiths or constructions of experience, 'the general time of society' somehow evades much scrutiny. The millennium itself provides many further examples of this unselfconscious acceptance of the clock, with regular reflections on Yeats's prophecies, and apocalyptic speculation about "what rough beast, its hour come round at last,/ slouches towards Bethlehem to be born" ("The Second Coming" 1921). Few commentators, however, seem to doubt that any rough beast involved would have carefully checked the time before setting off, using the same clock and calendar as everyone else, and not beastly ones of its own. Nor do they much reflect that if 'mere anarchy' were really loosed upon the world, the rough beast might show up early, or late, or not know the difference, if indeed it came to the right place at all. Even myth and nightmares in the late twentieth century are thus-in Flann O'Brien's memorable phrase- "infested by clocks" (198). Even when concluding that the clock is "the archetypal machine in our society" and that "the automation of time, in the clock, is the pattern of all larger systems of automation," Theodore Roszak acknowledges that "to experience time in any other way becomes 'mystical' or 'mad'" (228).

Not much, then, to be gained by cursing Greenwich at $11.59 \mathrm{pm}$ on 31 December 1999 , nor in trying to delay revellers in, say, Seville or Edinburgh, by explaining to them that the millennium really begins not at midnight but at, respectively, 12.24 or 12.13 , each city 
being several minutes west of Greenwich. Probably not much more point in suggesting, in the streets of either of these cities, that it might be worth following Joyce's conversion in Ulysses of "the bissextile year one thousand nine hundred and four of the Christian era" into the "jewish era five thousand six hundred and sixtyfive, mohammedan era one thousand three hundred and twentytwo" (780)—interesting as it might be to point out that the millennium is really only the year 2749 in Babylonian dating, 5119 in Mayan reckoning, 6236 for the Egyptians, or a mere 208 for anyone still going by the calendar established by the French Revolution. On the contrary, to argue about different numberings of minutes or of years is ultimately to remain complicit with processes of numbering and rationalisation themselves, and therefore implicitly with the interests of production, commodity and industry that have subtly, systematically imposed these upon the century just ceasing. More practically - though not necessarily at 11.59 on the last day of the millennium!-it may still be worth making the arbitrariness and constructedness of twentieth-century temporality accessible to analysis - the hours once again visible, viscous, even "sluggish, pale and monochrome" as Samuel Beckett describes them (4) - for any analysis of twentieth-century life, and certainly of twentieth-century narrative. As Ursula K. Heise suggests, "the novel [is] a genre whose organizational structures necessarily embody specific conceptions of time"(6). The structures of twentieth-century novels swerve from chronological organisation in direct proportion to their authors' nervousness about the coherence of contemporary history or the current 'conception of time': narrative temporality is one of the main channels through which history shapes literary imagination and form, with explicit references to the clock - of the sort which turn up so strikingly in V.-a kind of signpost of the stresses involved. Tracing such processes helps clarify one set of directions in which postmodernist writing clearly develops from its modernist precursor, and in which each, often at the level of form, responds to the stresses of a century so often shredded and sliced, cursed and reified by the hour. Almost in the carnival the spirit of those French picnickers, sitting down on their meridian on Bastille day in 2000, it is worth making some of the lines drawn across the space and time of the twentieth century as vividly apparent as possible, at least in order to identify and analyse various forms of the literary imagination's resistance to constraints a commodifying capitalist culture has consistently imposed upon it.

\section{WORKS CITED}

Barr, Armand. La Réforme du Calendrier. Liège: Charles Desoer, 1912.

Beckett, Samuel. Proust. London: Chatto and Windus, 1931.

Benjamin, Walter. 'Theses on the Philosophy of History' (1940). Rpt. Walter Benjamin Illuminations: Essays and Reflections. Ed. Hannah Arendt. New York: Schocken Books, 1978.

Conrad, Joseph. Lord Jim (1900). Rpt. Harmondsworth: Penguin, 1968.

The Secret Agent (1907). Rpt. Harmondsworth: Penguin, 1967.

Debord, Guy. Society of the Spectacle (1967). Detroit: Black and Red, 1973. 
Durrell, Lawrence. The Alexandria Quartet (1957-60). Rpt. London: Faber \& Faber, 1983.

Gibson, William. Neuromancer (1984). Rpt. London: Grafton, 1986.

Gray, Alasdair. Lanark (1981). Rpt. London: Granada, 1984.

Heise, Ursula K. Chronoschisms: Time, Narrative, and Postmodernism. Cambridge: Cambridge University Press, 1997.

Heller, Joseph. Catch-22 (1961). Rpt. London: Corgi, 1970.

Howse, Derek. Greenwich Time and the Discovery of the Longitude. Oxford: Oxford University Press, 1980.

Huxley, Aldous. Brave New World (1932) Rpt. London: Flamingo, 1994.

Jameson, Fredric. Fables of Aggression: Wyndham Lewis, the Modernist as Fascist Berkeley: University of California Press, 1979.

- Postmodernism, or, The Cultural Logic of Late Capitalism. London: Verso, 1991.

Joyce, James. Ulysses (1922). Rpt. Harmondsworth: Penguin, 1992.

Kern, Stephen. The Culture of Time and Space 1880-1918. Massachusetts: Harvard University Press, 1983

Lawrence, D.H. Fantasia of the Unconscious and Psychoanalysis and the Unconscious (1923). Rpt. London: Heinemann, 1961.

Women in Love (1921). Rpt. Harmondsworth: Penguin, 1971.

Lukács, Georg. History and Class Consciousness: Studies in Marxist Dialectics. Trans. Rodney Livingstone. London: Merlin Press, 1990.

McHale, Brian . Postmodernist Fiction. London: Methuen, 1987.

Nicholson, Colin and Randall Stevenson, “'Words you Never Wanted to Hear': Fiction, History and Narratology in The Crying of Lot 49."Pynchon Notes 16 (Spring 1985): 89109.

O’Brien, Flann. At Swim-Two-Birds Birds (1939). Rpt. Harmondsworth: Penguin, 1981.

Pinero, Arthur Wing. The Magistrate. In Three Plays. London: Methuen, 1985.

Pynchon, Thomas. V. (1963). Rpt. New York: Bantam, 1973.

Roszak, Theodore. The Making of a Counter Culture: Reflections on the Technocratic Society and its Youthful Opposition. London: Faber \& Faber, 1970.

Stevenson, Randall. "A Narrow, Zigzag, and Secluded Path: Conrad, Clockwork, and the Politics of Modernism." Aspects of Modernism. Eds. Andreas Fischer, Martin Heusser and Thomas Hermann. Tübingen: Gunter Narr Verlag, 1997. 
Taylor, Frederick Winslow. Principles of Scientific Management New York and London: Harper and Brothers, 1911.

Woolf, Virginia. Mrs Dalloway (1925). Rpt. Harmondsworth: Penguin, 1976.

Orlando (1928). Rpt. Harmondsworth: Penguin, 1975. 